O IMPACTO DO "PROJETO WASTENET" SOBRE A ECOLOGIA DA TURQUIA E GEORGIA

\title{
THE IMPACT OF "WASTENET PROJECT" ON THE ECOLOGY OF TURKEY AND GEORGIA
}

\author{
KIZILÖZ, Burak'; KUPATADZE, Ketevan²*; \\ ${ }^{1}$ Kocaeli Great Municipality, Water and Sewerage Administration, Manager of Darica Branch \\ Çağdaşkent, 526 Ave. 21/22 Çayırova 41400, Kocaeli, Turkey \\ (phone: +90 53555553 88; fax: +90262 7450497 )
}

$2^{2^{*}}$ Ilya State University, Faculty of natural sciences and engineering , Kakutsa Cholokashvili Ave 3/5 Tbilisi 0162, Georgia

(phone: +995 599 290905; )

* Corresponding author

e-mail: ketevan_kupatadze@iliauni.edu.ge

Received 17 December 2014; received in revised form 19 December 2014; accepted 22 December 2014

\section{RESUMO}

O artigo descreve o projeto: "A rede do Mar Negro promovendo sistemas naturais integrados de treatmento água - WASTEnet", que é dedicada a sistemas de tratamento de águas residuais. É dada a discussão de todos os tipos de Sistemas de Tratamento Natural, sua especificidade, processos químicos e biológicos que ocorrem durante o seu funcionamento. É mostrado o impacto deste projeto e NTS no exemplo de ecologia da Turquia e da Geórgia. O projeto apresentado ajuda as autoridades locais e regionais e as partes interessadas para obter uma visão sobre o papel das tecnologias inovadoras e amigas do ambiente, na melhoria do ambiente da região do Mar Negro.

Palavras-chave: Sistemas de tratamento natural; Terras alagadas construídas; Desperdício de água; Mecanismos de tratamento químico e biológico; WASTEnet.

\begin{abstract}
The article describes the project: "A Black Sea network promoting integrated natural Waste water treatment systems - WASTEnet," which is dedicated to wastewater treatment systems. There is given a discussion of all types of Natural Treatment Systems, their specificity, chemical and biological processes which take place during their functioning. There is shown the impact of this Project and NTS on the example of ecology of Turkey and Georgia. The presented Project helps local and regional authorities and stakeholders to gain insight on the role of innovative and environmentally-friendly technologies, in improving the environment of the Black Sea region.
\end{abstract}

Keywords: Natural Treatment Systems; Constructed wetlands; Waste water; Chemical and biological treatment mechanisms; WASTEnet;

PERIÓDICO TCHÊ QUÍMICA • www.periodico.tchequimica.com • Vol. 12 N. 23.

- ISSN 1806-0374 (impresso) • ISSN 1806-9827 (CD-ROM) • ISSN 2179-0302 (meio eletrônico)

(C) 2015. Porto Alegre, RS. Brasil 


\section{INTRODUCTION}

One of the main problems in the 21st century is Polluted Environment. From all the environmental factors I would like to emphasize the importance of water, because every polluted agent can be solved in water yielding different pollutant substances. Ions of heavy metals can be transformed into soluble forms in water and can be spread into soil (by underground wastewater) and into troposphere with the aerosols spreading from water surfaces. The most important factor in water pollution is untreated domestic, industry, animal wastewater.

Wastewater is the liquid end-product, or by-product, of municipal, agricultural, and industrial activity. As such, the chemical composition of wastewater naturally reflects its origin. The term 'wastewater', however, implies that it is a waste product to be discarded in an environmentally sound manner. On the average, the overall wastewater generation rate varies significantly from country to country.

The Black Sea project "A Black Sea network promoting integrated natural Waste water Treatment systems - WASTEnet" where participate seven country from Black Sea region, is dedicated to this problem. This countries are: Greece, Moldova, Armenia, Georgia, Turkey, Romania, Ukraine. The project is educational and the main purpose is spreading information about the Natural Treatment System (NTS) especially about constructed wetlands. That is why in scope of project different educational printed material are relised. In every participant country was held technical seminar and workshop.

In general, Natural Treatment Systems are divided in four broad types:

Terrestrial treatment methods

These methods depend on the physical, chemical and biological reactions on and within the soil matrix. The wastewater after a preliminary treatment step is disposed on the soil (vegetated or not). Technologies comprise slow rate, rapid infiltration and overland flow systems, as well as combinations of these types. In slow rate (SR) and overland flow (OF) methods, vegetation constitutes a significant treatment component while in rapid infiltration, vegetation is not necessary (Figure1).

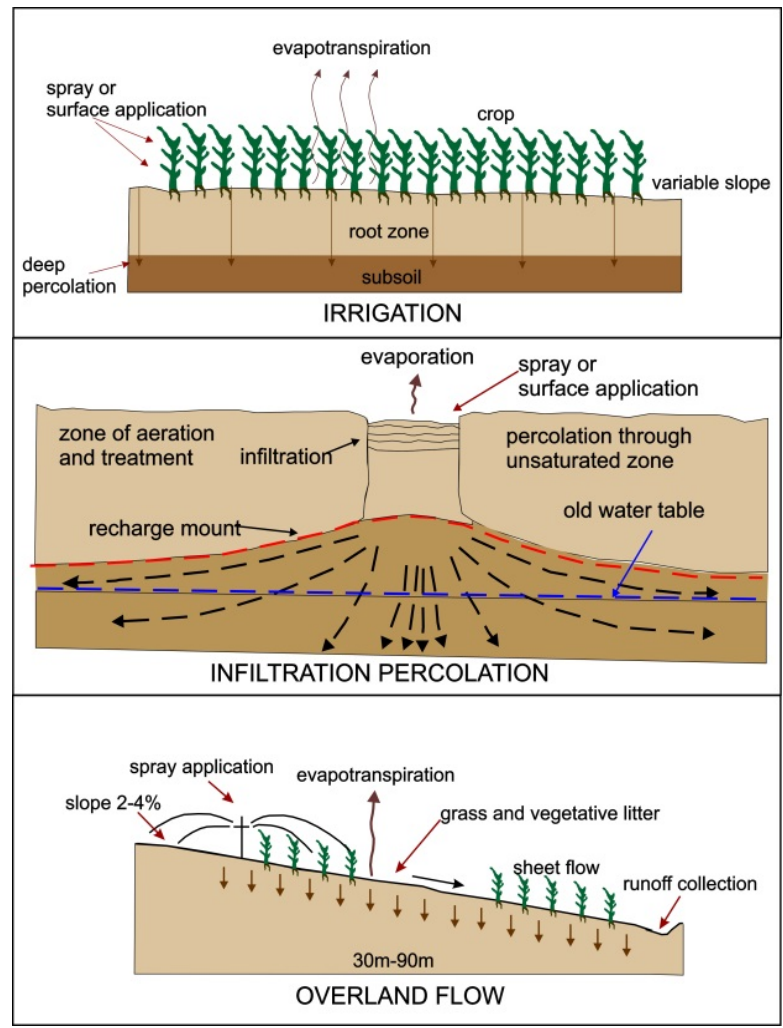

Figure 1. Methods of land application

\section{Wastewater stabilization ponds}

They are open ponds, whose treatment function depends on sun light, the microbial life and the lower forms of plants and animals. Organic matter is decomposed naturally, i.e., biologically. With the contribution of bacteria and algae, wastewater is stabilized and its pathogens are reduced. Generally organic content of the effluent is converted to more stable forms. Stabilization ponds include various types, as: sewage lagoons, and oxidation, redox, maturation, facultative, anaerobic, aerobic and aerated ponds. They can be used in a wide range of weather conditions alone, in series of various pond types (the common series is anaerobic, facultative and maturation ponds), or in combination with other wastewater treatment systems.

\section{Aquatic plant systems}

They are similar to stabilization ponds but they also treat wastewater through their content 
of higher plants and animals. Such systems may be divided in those with floating plants and those with submerged plants. Their extensive root system generates a substrate for micro-organism growth, which contributes to the removal of pollutants, thus achieving the best possible treatment.

\section{Constructed wetlands}

CWs are man-made, engineered systems designed to simulate the function of natural wetlands in pollutant removal. To achieve wastewater treatment, a series of physical, chemical and biological processes take place in CWs, based on water, soil, atmosphere (i.e. sun and wind) and micro-organism interactions. Wetland plants play a vital role in the removal and retention of organic matter, nutrients, heavy metals and various toxic substances. The common reed (Phragmites australis) and the cattail (Typha latifolia, T. angustifolia) are good examples of marsh species that can effectively uptake pollutants, and therefore, are commonly used in CWs.

Three are the most common CW types: Free Water Surface (FWS) systems, Horizontal Subsurface Flow (HSF) systems and Vertical Flow (VF) systems.

\section{Free-water surface CWS}

They consist of one or more vegetated shallow impermeable basins or channels (40 to $60 \mathrm{~cm}$ deep) filled with soil, planted native vegetation (e.g., cattails, reeds and/or rushes), and equipped with appropriate inlet and outlet structures. The wastewater flows at depths 10 to $30 \mathrm{~cm}$ or even $45 \mathrm{~cm}$, and is exposed to the atmosphere, the wind and direct sunlight.

An anoxic/anaerobic zone prevails at the bottom of the wetland, while an aerobic zone exists near the surface oxygenated through atmospheric re-aeration aided by the plant movement by the wind. As the wastewater flows through the wetland, simultaneous physical, chemical and biological processes remove the pollutants. Although the soil layer below the water is anaerobic, the plant roots release oxygen into the area creating an environment of complex biological and chemical activity (Figure2).

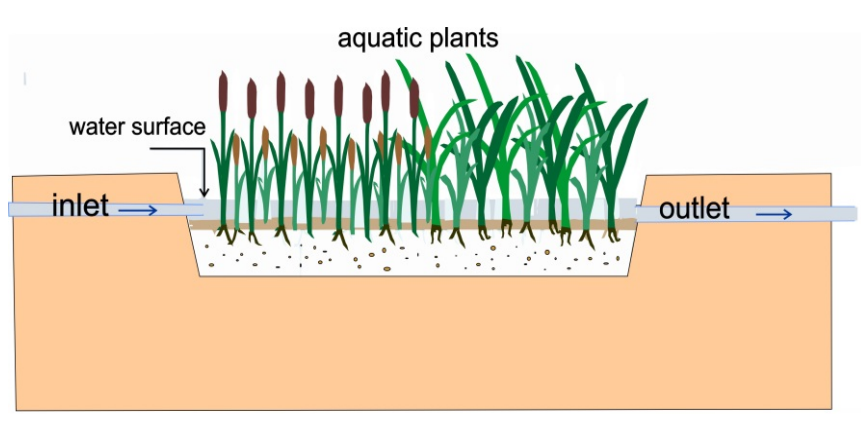

Figure 2. Schematic of a free-surface wetland

\section{Horizontal Subsurface Flow CWS}

They are large gravel and sand-filled channels, planted with aquatic vegetation. The bed is 0.5 to $1 \mathrm{~m}$ deep $(3-32 \mathrm{~mm}$ in grain size diameter) and is lined over an impermeable liner (clay or impermeable geo membrane) in order to prevent leaching. Wastewater is intended to stay beneath the surface of the porous media flowing within the pores and around the roots and the rhizomes of the plants. The bed should be wide and shallow so that the flow path of the water is maximized. A wide inlet zone is used to evenly distribute the flow. The bottom slope is normally $1 \%$. Regarding wetland vegetation any plant with deep, wide roots that can grow in the wet, nutrient-rich environment may be considered as appropriate for such systems. Wastewater is purified as it comes in contact with the filter media and plant roots (Figure 3 ).

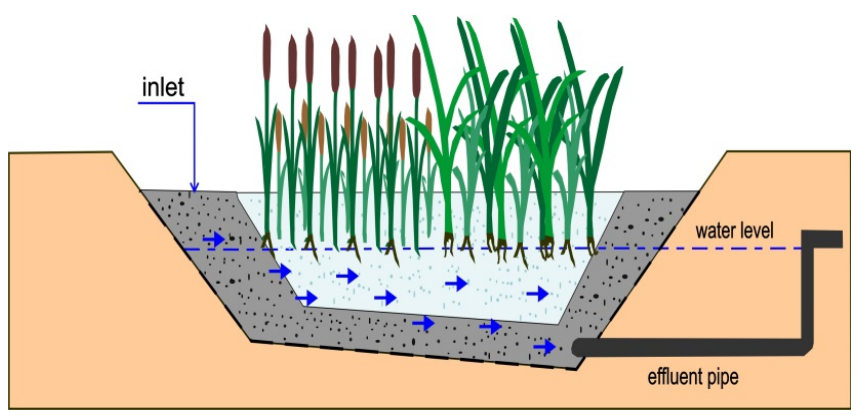

Figure 3. Schematic of a horizontal subsurface flow CW 


\section{Vertical flow CWS}

They are filter beds planted with aquatic plants. Wastewater is introduced to the wetland surface through a network of perforated pipes in order to achieve uniform flooding. The water percolates by gravity downwards through the filter matrix. It reaches then the drainage layer (bottom), which contains a network of perforated collection and aeration tubes. The bed contains various layers of different gradation. The first layer near the bed comprises gravel used for drainage (at minimum $20 \mathrm{~cm}$ thick), followed on top by layers of gravel and sand (surface layer $10-30 \mathrm{~cm}$ thick). The top layer is planted and the vegetation is allowed to develop deep, wide roots which permeate the filter media. The total depth varies from $0.90 \mathrm{~m}$ to $1.20 \mathrm{~m}$. A bed slope of $1 \%$ is needed for drainage.

Vertical flow CWs can operate with: Intermittent flow, unsaturated downflow, saturated up or downflow and tidal flow. Two phases appear on these systems: the flush and the drying phase. Depending on the climate, Phragmites australis, Typha latifolia or Echinochloa Pyramidalis are common options. The important difference between a vertical flow and the horizontal subsurface flow CWs is not simply the direction of the flow path, but rather the fill and dry cycles and the enhanced aerobic conditions in the VF case, factors leading to reduced area requirements [1-3].

\section{Constructed wetland treatment mechanisms}

Constructed wetlands utilize the natural processes (wetland vegetation, soil, microbial activity) within a more controlled environment in order to remove pollutants. The main removal mechanisms can be divided in abiotic (physical and chemical) and biotic (biological) processes. The abiotic processes that are responsible for removing pollutants in a constructed wetland are:

a) Settling and sedimentation, which contribute to particulate matter and suspended solids removal

b) Adsorption and absorption, which take place on the surfaces of plants, substrate, sediments, and litter and result in shortterm retention or long-term immobilization of contaminants

c) Chemical oxidation / reduction / precipitation, where influent metals convert to an insoluble solid form and are immobilized when water comes in contact with the substrate and litter

d) Photodegradation, oxidation and degradation of compounds in the presence of sunlight

e) Volatilization - which occurs when volatile compounds partition to the gaseous state

Respectively, the biotic processes are:

a) Aerobic/anaerobic biodegradation by microorganism metabolic activities

b) Phyto-accumulation of inorganic elements

c) Phyto-stabilization - the ability to sequester inorganic compounds in plant roots

d) Phyto-degradation of organic and inorganic contaminants that enter into the plant during transpiration by enzymes that plants produce

e) Rhizo-degradation by exudates that plant produce which lead to microbial degradation of organic compounds

f) Phyto-volatilization/evapotranspiration achieved by plant leaves (Table 1).[4-5]

Table 1. Removal mechanisms of certain contaminants

\begin{tabular}{c|c}
\hline $\begin{array}{c}\text { Pollutant } \\
\text { removal }\end{array}$ & Process \\
\hline $\begin{array}{c}\text { Organic } \\
\text { matter }\end{array}$ & $\begin{array}{c}\text { Biological degradation, } \\
\text { sedimentation, microbial } \\
\text { consumption }\end{array}$ \\
\hline $\begin{array}{c}\text { Suspended } \\
\text { solids }\end{array}$ & Sedimentation, filtration \\
\hline Nitrogen & $\begin{array}{c}\text { Sedimentation, } \\
\text { nitrification/denitrification, microbial } \\
\text { consumption, plant uptake, } \\
\text { gasification }\end{array}$ \\
\hline Phosphorus & $\begin{array}{c}\text { Sedimentation, filtration, } \\
\text { adsorption, plant and microbial } \\
\text { consumption }\end{array}$ \\
\hline Pathogens & $\begin{array}{c}\text { Natural death, sedimentation, } \\
\text { filtration, UV degradation, } \\
\text { adsorption }\end{array}$ \\
\hline $\begin{array}{c}\text { Heavy metals } \\
\text { Organic } \\
\text { compounds } \\
\text { (pesticides, } \\
\text { etc) }\end{array}$ & $\begin{array}{c}\text { Sedimentation, adsorption, plant } \\
\text { udstake }\end{array}$ \\
\hline
\end{tabular}




\section{NTS vS. CONVENTIONAL TREATMENT SYSTEMS}

Conventional Treatment Systems (CTS) for wastewater offer a combination of physical, chemical, and biological processes and operations taking place within an artificial environment, in order to remove solids, organic matter and even nutrients from wastewater. The Natural Treatment Systems (NTS) attempt to simulate the naturally occurring processes of wastewater degradation and contribute to the removal of pollutants. When natural systems are incorporated into a natural landscape or a building design, they can provide added benefits compared to a conventional treatment system.

Compared to conventional wastewater treatment systems, natural systems are more ecologically and economically efficient. NTS use natural processes and renewable energy sources in order to treat wastewater. These systems may also provide indirect benefits, such as aesthetic improvement of the landscape, creation of wildlife habitat, and recreational and educational opportunities.

The design and construction of NTS is very simple in comparison to CTS. NTS require low construction, labor and maintenance costs in comparison to the CTS for the treatment of the same volume of wastewater. In addition, CTS require frequent monitoring and specialized staff, while these requirements do not appear on a NTS. The only limiting factor is the availability and the cost of land to place the treatment plants.

For the construction of wastewater treatment plants, various materials are used, such as concrete, steel, polyvinyl chloride (PVC), polyethylene (PE), soil materials, etc. Wastewater treatment is based on several processes where there is need of chemicals, electricity, air supply, etc.; treatment by products are also produced, such as sewage sludge, methane, carbon dioxide, etc. The use and production of these materials and substances have a certain, low or high, environmental impact. Natural systems, on the contrary, do not require these materials or chemicals.

While conventional systems consume large quantities of energy for their operation, natural systems do not require mechanical devices and depend only on natural processes and renewable energy sources. When a CTS experiences an occasional process upset (unexpectedly high loads), these leads to worse effluent values, thus worse efficiency. Worth noting is the fact that CTS create secondary problems in sludge disposal. This problem not only does not appear on NTS but also NTS are very reliable even in extreme operating conditions. They can absorb a wide variety of hydraulic and organic feed. In addition, NTS plants can perform as well as CWT plants do for the removal of most of the pollutants.

A NTSs drawback is the fact that they are vulnerable and susceptible to climate, while CTSs are well protected. Climatic variations in particular may affect the performance of the NTS [6-7].

\section{RESULTS AND DISCUSSION:}

According the study done in scope of the project situation in the two neighbouring countries - Turkey and Georgia, is following.

\section{Waste water treatment in Georgia}

According the study which is made in different countries bordering on the Black Sea coast (such as: Turkey, Georgia, Ukraine, Moldova, Armenia, Romania, Greece) the main water pollutant agent are: heavy metals, nitrites, nitrates, ammonia, phosphates, organic compounds, phenol and ect.

From already mentioned country only in Georgia there is no practice of construction of natural treatment systems. Others have quiete interesting experience in this field.

Presently in Georgia, almost all wastewater treatment plants are inoperable. Nationally, there is only one fully operational waste water treatment plant (WWTP) in Sachkhere. Another, in Gardabani, provides only primary, mechanical treatment. The Gardabani WWTP receives municipal wastewaters from the capital, Tbilisi, and the city of Rustavi (in this city there is a huge factory which make fertilizers and other chemicals. It has his own laboratory and cares about own waste). However, a significant volume of untreated urban wastewater from Tbilisi and Rustavi discharges directly into the Mtkvari River. 
As we mentioned already In Georgia there no experience using NTS. The first attempt was in 2010 when the Wood Service in partnership with Dutch company Ecofyt initiated launch of a natural alternative system of wastewater treatment in Georgia - Constructed Wetlands. This system represented an artificial treatment reservoir with main purpose of water purification.

In 2011 Wood Services was planning to build two constructed wetlands: first one at Ecohotel on Bazaleti Lake and second one at Aragvi Adventure Center in Tvalivi village. Though, later, due to various causes, these plans have not been implemented.

After above mentioned unsuccessful attempt, WASTnet project in Georgia is the first and very important in scope of which the information about Natural Treatment System (NTS) especially about constructed wetlands will be spreading and the mean goal of this project is convince local authorities in advantage of NTS towards conventional cleaning systems.

We want underlined one circumstance. All above listed places in Georgia are included in the touristic routes because they are interested places in ecological point of view. Ecotourism is a very good mean to spread information about types of natural treatment systems. Despite the fact, that there is long time since such natural treatment systems exist, information about them is still limited and needs to be spread within wider audiences.

In eco touristic point of view Zoo are also very interested places for constructed wetland and according the world experience they exist in many Zoo of European country and USA.

So, if we summarized the WESTnet project has quiet large impact to spreading information about NTS advantage towards conventional cleaning system and Georgia in future can successfully use experience from other countries participating in the project.

\section{Waste water treatment in Turkey}

In Turkey, wastewater treatment facilities or natural treatment methods are used. In places where both population and flow rate is high, activated sludge, activated sludge with extended aeration activated system, stabilization pool, sequential batch reactor, trickling filter and membrane systems are used in wastewater treatment facilities as treatment methods. Constructed wetlands, which are one of the natural wastewater treatment methods, are used in settlements with low population. Using treated wastewater in irrigation is also a common method in countries with water scarcity. Treated wastewater obtained by applying advanced treatment and disinfected with extended aeration activated sludge method in some of the wastewater treatment projects done by Iller Bank in Turkey, are discharged to dams with purposes of irrigation or to irrigation ponds and water collected here are used as irrigation water.

In Turkey, generally, wastewater treatment plants which treat wastewater in extended aeration activated sludge process are used. For the places where there is low population and large empty land (if adequate for a treatment plant), stabilization ponds, natural treatment with constructed wetland and modular wastewater treatment systems with activated sludge system principle are used. Since natural treatment methods such as leaking the raw wastewater directly underground, letting it into slanted land or evaporating are highly dangerous from the point of human health, these are not used in Turkey. Stabilization ponds are the simplest of all the wastewater treatment methods, and provide an advantage of not having any energy expenditure, high reliability, ease in maintenance and operation. Constructed wetlands with subsurface runoff are preferred in general due to odor and fly problems, which are the main problems of constructed wetlands with subsurface runoff. Constructed wetlands with subsurface runoff are divided into two: with vertical and horizontal runoff. In domestic wastewater treatment with different wetlands which have different types of plants and runoff, $80-99 \%$ BOD5, COD and bacteria removal, 92$95 \%$ SS, $30-80 \%$ total nitrogen and $20-70 \%$ total phosphorus is obtained.

\section{Kocaeli Treatment Plants}

Kocaeli is a province of Turkey. Its capital is Izmit, which is also sometimes called Kocaeli. The largest towns in the province are Izmit and Gebze. The province is located at the 
easternmost and of the Marmara Sea around the Gulf of Izmit. Kocaeli is bordered by the province of Sakarya and the Marmara Sea to the west, the Black Sea to the north, the province of Istanbul the east, the province of Bursa to the south and the province of Yalova to the south west. Kocaeli is industrial place which is necessary for city development and at the same time it is necessary to keep ecological systems in good conditions for city. Marmara Sea, Black Sea and Gulf basin have to be protected from pollution stem from waste water. For his reason a lot treatment plants which are operated by Kocaeli Water and Sewerage Administration (KWSA) refined to $\% 100$ waste water of Kocaeli in 2014 (Table 2 and 3) [8].

Table 2. Management of Waste Water Treatment Plants by KWSA

\begin{tabular}{c|c}
\hline $\begin{array}{c}\text { Operating } \\
\text { W.W.T.P }\end{array}$ & $\begin{array}{c}\text { Operating } \\
\text { Modular W.W.T.P }\end{array}$ \\
\hline 42 Evler & Bağırganlı \\
\hline Kullar & Valide köprü \\
\hline Körfez & Akmeşe \\
\hline Yeniköy & Hakkaniye \\
\hline Karamürsel & Cavuslu \\
\hline Plajyolu & Tavsancıl \\
\hline Gebze & Mutlukent \\
\hline Kandıra & ------ \\
\hline Cebeci & ----- \\
\hline
\end{tabular}

Table 3. Management of Waste Water Treatment Plants by KWSA

\begin{tabular}{c|c}
\hline PARAMETETERS & $\begin{array}{c}\text { IN TWO HOUR } \\
\text { COMPOSITE } \\
\text { SAMPLE } \\
\text { ALLOWED } \\
\text { VALUE }\end{array}$ \\
\hline COD (mg/l) (a) & 800 \\
SS (mg/l) & 350 \\
Total Nitrogen $(\mathrm{mg} / \mathrm{l})$ & 100 \\
Total Phosphorus $(\mathrm{mg} / \mathrm{l})$ & 10 \\
Oil and Grease $(\mathrm{mg} / \mathrm{l})$ & 50 \\
Arsenic $(\mathrm{As})(\mathrm{mg} / \mathrm{l})$ & 3 \\
Antimony $(\mathrm{Sb})(\mathrm{mg} / \mathrm{l})$ & 3 \\
Tin $(\mathrm{Sn})(\mathrm{mg} / \mathrm{l})$ & 5 \\
Iron (Fe) $(\mathrm{mg} / \mathrm{l})$ & 5 \\
Boron $(\mathrm{B})(\mathrm{mg} / \mathrm{l})$ & 3 \\
Cadmium $(\mathrm{Cd})(\mathrm{mg} / \mathrm{l})$ & 2 \\
Total Chromium $(\mathrm{Cr})(\mathrm{mg} / \mathrm{l})$ & 5 \\
Copper $(\mathrm{Cu})(\mathrm{mg} / \mathrm{l})$ & 2 \\
\hline
\end{tabular}

\begin{tabular}{c|c}
\hline Lead $(\mathrm{Pb})(\mathrm{mg} / \mathrm{l})$ & 3 \\
Nickel $(\mathrm{mg} / \mathrm{l})$ & 5 \\
Mercury $(\mathrm{Hg})(\mathrm{mg} / \mathrm{l})$ & 0,2 \\
Silver $(\mathrm{Ag})(\mathrm{mg} / \mathrm{l})$ & 5 \\
Total Cyanide $(\mathrm{CN})(\mathrm{mg} / \mathrm{l})$ & 10 \\
Phenol $(\mathrm{mg} / \mathrm{l})$ & 20 \\
Total Sulfur $(\mathrm{mg} / \mathrm{l})$ & 2 \\
Free Chlorine $(\mathrm{mg} / \mathrm{l})$ & 5 \\
Sulfate $\left(\mathrm{SO}_{4}\right)(\mathrm{mg} / \mathrm{l})(\mathrm{c})$ & 1700 \\
Temperature $\left(\mathrm{O}^{\circ} \mathrm{C}\right)$ & 40 \\
$\mathrm{pH}$ & $6-10$ \\
\hline
\end{tabular}

Domestic, Agricultural and Industrial wastewater located in Kocaeli province should not exceed the discharge limits indicated Wastewater Sewage Discharge Regulation in order to be discharged in sewage system. Wastewater sources which are above the discharge limits indicated in Table 4. must be pretreated and lowered to below the discharge limits or must be disposed in firms which obtained the Industrial and Domestic Wastewater treatment license before discharging in the sewage system, and such disposal must be proven to Izmit Water and Sewage Administration with the disposal documents (Pre-treatment cost belongs to the wastewater source owner) (Table 4) [9].

Table 4. Limit values, which must be complied with Izmit Water and SewageAdministration Collector System in Wastewater discharges

\begin{tabular}{c|c}
\hline Opreating NTS & $\begin{array}{c}\text { Planning } \\
\text { W.W.T.P. }\end{array}$ \\
\hline Balçık & Sucuali Modüler \\
Kullar & Akcova Modüler \\
Körfez & Dilovası \\
\hline
\end{tabular}

\section{CONCLUSIONS:}

Constructed wetlands have been recognized as a reliable wastewater treatment technology and, at present, they represent a suitable solution for treatment of many types of wastewater. However, constructed wetlands are better suited for smaller applications. The use of constructed wetlands for various industrial effluents is now also common. At present, constructed wetlands are a viable alternative in wastewater treatment technology and there are tens of thousands of applications in all parts of 
the world.

In the first decades of the 21st century, the technology of wastewater treatment in constructed wetlands could be characterized by the following:

a) combination of various types of constructed wetlands in hybrid systems to achieve better treatment performance, especially for nitrogen;

b) treatment of specific compounds present in wastewaters;

c) search for suitable media with high capacity for phosphorus removal in subsurface flow constructed wetlands;

d) identification of bacteria which assist in treatment processes;

e) modeling of hydraulics and pollution removal in various types of constructed wetlands.

The projects like "WASTEnet" are very useful for The popularization Natural Treatment System (especially, Constructed wetlands) for the county with no experience - as Georgia and also for country with large experience in this field -as Turkey (and others).

\section{ACKNOWLEDGMENTS:}

The authors would like to express their warm acknowledgments to Prof. Georgios Sylaios (Democritus University of Thrace, Greece) and to all the team of the project- $A$ Black Sea network promoting integrated natural WAStewater Treatment systEms - WASTEnet. The project is financed by the EU INTERREG IV "Black Sea Basin Joint Operational Programme 2007-2013".

\section{REFERENCES:}

1. Kadlec R.K., Wallace S.D. Treatment Wetlands. Second Edition, CRC Press, Taylor \& Francis Group, New York. 2009, p. 27-40.

2. Tsihrintzis V.A., Gikas G.D. Constructed wetlands for wastewater and activated sludge treatment in north Greece: a review. Water Science and Technology, 2010, 61 (10): 2653-2672.

3. Vymazal J., Constructed Wetlands for Wastewater Treatment: Five Decades of Experience. Environmental Science and Technology, 2011, p. 61-69.

4. Sylaios G. Educational Material. Press of Ilia State University (translation in Georgian). 2014, p.10-11.

5. Zhi W., Ji G. Constructed wetlands, 1991-2011: A review of research development, current trends, and future directions. Science of the Total Environment, 2012, p. 19-27.

6. Vymazal J., Removal of nutrients in various types of constructed wetlands. Science of the Total Environment, 2007, p. 48-65.

7. Ronald W., Crites E., Bastian K. Natural Wastewater Treatment Systems. Second Edition. CRC Press. 2014. P. 34-37.

8. Kiziloz B., Kupatadze K.. Natural Treatment Technologies (Dogal Aritma Teknolojileri, in Turkish). iMOKOCAELI. 2014.59-63.

9. Kupatadze K., Kiziloz B. Utilization of WASTnet project in water purification process. Annals of Chemistry. Journal of Association of Professional Chemists of Georgia (in Georgian). 2014. P.5-9. 